Research Article

\title{
Fresh and Hardened Properties of Concrete Incorporating Binary Blend of Metakaolin and Ground Granulated Blast Furnace Slag as Supplementary Cementitious Material
}

\author{
Naraindas Bheel, ${ }^{1}$ Suhail Ahmed Abbasi, ${ }^{2}$ Paul Awoyera $\left(\mathbb{D},{ }^{3}\right.$ Oladimeji B. Olalusi $\left(\mathbb{D},{ }^{4}\right.$ \\ Samiullah Sohu, ${ }^{2}$ Carlos Rondon, ${ }^{5}$ and Ana María Echeverría ${ }^{5}$ \\ ${ }^{1}$ Department of Civil Engineering, Universiti Teknologi Petronas, Bandar Seri Iskandar, Tronoh, Perak 31750, Malaysia \\ ${ }^{2}$ Department of Civil Engineering, Quaid-e-Awam University of Engineering, Science \& Technology, Larkana, Pakistan \\ ${ }^{3}$ Department of Civil Engineering, Covenant University, Ota, Nigeria \\ ${ }^{4}$ Department of Civil Engineering, Structural Engineering \& Computational Mechanics Group (SECM), \\ University of KwaZulu-Natal, Durban, South Africa \\ ${ }^{5}$ Universidad de la Costa, Barranquilla, Colombia
}

Correspondence should be addressed to Paul Awoyera; paul.awoyera@covenantuniversity.edu.ng

Received 17 September 2020; Accepted 30 September 2020; Published 10 October 2020

Academic Editor: Mehmet Serkan Kirgiz

Copyright (c) 2020 Naraindas Bheel et al. This is an open access article distributed under the Creative Commons Attribution License, which permits unrestricted use, distribution, and reproduction in any medium, provided the original work is properly cited.

\begin{abstract}
The growing demand for cement has created a significant impact on the environment. Cement production requires huge energy consumptions; however, Pakistan is currently facing a severe energy crisis. Researchers are therefore engaged with the introduction of agricultural/industrial waste materials with cementitious properties to reduce not only cement production but also energy consumption, as well as helping protect the environment. This research aims to investigate the influence of binary cementitious material (BCM) on fresh and hardened concrete mixes prepared with metakaolin (MK) and ground granulated blast furnace slag (GGBFS) as a partial replacement of cement. The replacement proportions of BCM used were $0 \%, 5 \%, 10 \%, 15 \%$, and $20 \%$ by weight of cement. A total of five mixes were prepared with $1: 1.5: 3$ mix proportion at 0.54 water-cement ratios. A total of 255 concrete specimens were prepared to investigate the compressive, tensile, and flexural strength of concrete after 7, 28, and 56 days, respectively. It was perceived that the workability of concrete mixes decreased with an increasing percentage of MK and GGBFS. Also, the density and permeability of concrete decreased with an increasing quantity of BCM after 28 days. Conversely, the compressive, tensile, and flexural strength of concrete were enhanced by $12.28 \%, 9.33 \%$, and $9.93 \%$, respectively, at $10 \%$ of BCM after 28 days. The carbonation depth reduced with a rise in content of BCM (up to 10\%) and then later improved after 28, 90, and 180 days. Moreover, the effect of chloride attack in concrete is reduced with the inclusion of BCM after 28 and 90 days. Similarly, the drying shrinkage of concrete decreased with an increase in the content of BCM after 40 days.
\end{abstract}

\section{Introduction}

Concrete is a widely used construction material all over the world. Due to its adaptability and relative profitability, it is considered a competitive building material [1]. Concrete includes cement, aggregate, and water. The component aggregates make up from $75 \%$ to $80 \%$ of the total volume of concrete, which affects the essential properties of fresh and hardened concrete, as well as the performance of concrete
$[2,3]$. Cement production has some disadvantages, like high production costs, and its production requires a lot of energy. Cement production also leads to the massive production of carbon dioxide and other greenhouse gases. Previous studies $[4,5]$ reported that about 1 to 1.25 tons of carbon dioxide is emitted during the production of one ton of cement and about 1.60 MWh of energy is required. Cement production is considered an expensive and environmentally unfriendly process [6]. According to earlier studies [7], human activity 
on Earth produces more than 5000 tons of solid waste every year, including industry and agriculture.

Solid waste includes important components such as silica fume, rice husk ash [8], fly ash, and corn cob ash. When these byproducts are used under the weight of cement, a lot of money will be saved, and the energy consumption will be reduced [9]. Use agricultural waste such as rice husk ash, bagasse ash, waste glass powder, fly ash, and straw ash [10]. To reduce costs, waste, and carbon dioxide emissions, these resources are readily available $[11,12]$. In this pilot study, the combination of metakaolin $(\mathrm{MK})$ and ground granulated blast furnace slag (GGBFS) (byproduct of industrial waste) is considered as wastes because it creates environmental pollution. The performance of both pozzolans is almost identical with similar replacement level for enhancing the compressive strength and improving the permeability of concrete [13]. However, the use of metakaolin offers higher strength development of the interfacial transition zone than the other materials [14]. Metakaolin is a natural pozzolanic material, and it is a primary product which is achieved by burning kaolin clay under the controlled temperature of $650-800^{\circ} \mathrm{C}$. Over the past decades, MK has been commercially introduced in the concrete construction industry [15]. There are several studies conducted on the strength development of concrete containing $\mathrm{MK}$ in concrete. Those studies have revealed that the use of MK showed considerable enhancement in strength development.

Poon et al. [16] investigated the effects of metakaolin content on hardened concrete. They reported that increasing the amount of $\mathrm{MK}$ in concrete enhances the strength and decreases the concrete porosity. MK concrete having a $0.5 \mathrm{w} /$ $\mathrm{b}$ ratio performed better as compared to $0.3 \mathrm{w} / \mathrm{b}$ ratio with regards to strength development. The porosity and pore size of concrete significantly decreased at 28 days of curing. At the same time, Jin and $\mathrm{Li}$ [17] reported a similar trend. Ahmed et al. [18] described that the crushing and flexural strength were improved with the inclusion of $15 \% \mathrm{MK}$ in concrete. The performance of MK concrete was also better for permeability-related properties of concrete. Dinakar et al. [19] observed replacement of $10 \% \mathrm{MK}$ in concrete as the ideal substitution for compressive strength. It was achieved by $106 \mathrm{MPa}$ while $10 \%$ of cement replaced with MK whereas splitting tensile strength and values elastic modulus also showed a similar trend. In relation to this, the findings are also consistent with other studies [20, 21]. Moreover, ground granulated blast furnace slag is a waste material from the metallurgical industry. A mixture of limestone, iron ore, and coke enters the kiln under temperatures from 15,000 to $16,000^{\circ} \mathrm{C}$; the resulting molten slag is suspended in molten iron. The slag contains 35 to $45 \%$ silicon dioxide $\left(\mathrm{SiO}_{2}\right)$ and about $45 \%$ calcium oxide. The slag chemical composition is almost the same as that of ordinary Portland cement (OPC). When the molten iron is removed, the molten slag containing the silicon-containing aluminium slag rapidly sinks into the liquid, thereby forming glassy particles [22-27]. The glassy particles are dehydrated and then pressed to the required size [28, 29]. This ground slag is called ground granulated blast furnace slag. Ground granulated blast is eco-environmental construction material. By replacing cement with crushed blast furnace slag, carbon dioxide emissions can be controlled to a certain extent [23, 30]. GGBFS improves concrete impermeability as well as corrosion and sulfate resistance. Considering these characteristics, the service life of the concrete structure is increased, and maintenance costs may be reduced. The high proportion of the eco-environment GGBFS for cement replacement results in the concrete not only using waste but also protecting the consumption of natural resources and energy $[31,32]$.

Investigations conducted by Cervantes and Roesler [33] found that the compressive and flexural strength of GGBFS concrete increase with increasing content of GGBFS after 28 days. Karrri et al. [24] investigated the influence of GGBFS on the freshness and strengthening properties of concrete. In this study, concrete grades M20 and M40 were studied, replacing cement with 30,40, and 50\% GGBFS. The experimental outcomes were noted that the workability of concrete was inclined with the increases in replacement level of GGBFS. However, the compressive, tensile, and flexural strength were enhanced with the inclusion of GGBFS content in concrete after 28 and 90 days, respectively.

In the available literature, there are a limited number of studies available on the individual and combined effects of MK and GGBFS as cement replacing material in concrete. Several types of mineral admixtures are used in concrete, but their effects on concrete properties with binary and ternary blends are not much investigated. The purpose of this investigational study is to examine the combined influence of MK and GGBFS as BCM on fresh and hardened concrete.

\section{Materials and Methods}

2.1. Materials. In this study, Portland cement (PC), metakaolin, and GGBFS are utilized as binding materials in concrete. The chemical composition of the binding materials is presented in Table 1. Metakaolin is a natural pozzolanic material, obtained by burning kaolin clay under a controlled temperature arrangement of $650-800^{\circ} \mathrm{C}$. After burning, it was sieved through $75 \mu \mathrm{m}$ to remove the unwanted materials. Moreover, GGBFS is a waste product obtained from the mixture of limestone, iron ore, and coke in the kiln under temperatures ranging from 15,000 to $16,000^{\circ} \mathrm{C}$; the resulting molten slag is suspended in molten iron. The obtained slag is sieved through $75 \mu \mathrm{m}$, and it is utilized as a cement substitution in concrete. The hill sand was used as fine aggregates (FA) having size $4.75 \mathrm{~mm}$, and crushed stone was used as coarse aggregates (CA) of $20 \mathrm{~mm}$ in size. The physical properties of the aggregates are presented in Table 2. The potable water was utilized for this experimental work.

2.2. Research Methodology. In this experimental work, five concrete mixes were prepared with the introduction of different percentages of MK and GGBFS as presented in Table 3. An equal quantity of MK and GGBFS is utilized as a binary cementitious material (BCM) for replacement of cement up to $20 \%$, in which concrete mix was made with the inclusion of $0 \% \mathrm{BCM}$, and the remaining four mixtures were 
TABLE 1: Chemical composition of binders.

\begin{tabular}{lccc}
\hline Compound & PC & MK & GGBFS \\
\hline $\mathrm{SiO}_{2}$ & 20.78 & 54.60 & 37.22 \\
$\mathrm{Al}_{2} \mathrm{O}_{3}$ & 5.11 & 33.40 & 10.37 \\
$\mathrm{Fe}_{2} \mathrm{O}_{3}$ & 3.17 & 2.88 & 1.23 \\
$\mathrm{CaO}$ & 60.22 & 3.40 & 35.66 \\
$\mathrm{Na}_{2} \mathrm{O}$ & 0.18 & - & 0.23 \\
$\mathrm{SO}_{3}$ & 2.86 & 0.47 & 0.34 \\
Specific gravity & 3.15 & 2.34 & 2.25 \\
\hline
\end{tabular}

TABLE 2: Physical properties of the aggregate.

\begin{tabular}{lcc}
\hline Property & FA & CA \\
\hline Fineness modulus & 2.35 & - \\
Specific gravity & 2.60 & 2.68 \\
Absorption $(\%)$ & 1.54 & 0.77 \\
Bulk density $\left(\mathrm{kg} / \mathrm{m}^{3}\right)$ & 1780 & 1640 \\
\hline
\end{tabular}

prepared with the addition of $5 \%, 10 \%, 15 \%$, and $20 \%$ BCM, respectively. The concrete specimens were cast using $1: 1.5$ : 3 mix ratio with a 0.54 water-cement ratio. A total of 255 numbers of concrete specimens (cubes, cylinders, and prisms) were studied.

\subsection{Testing Methods}

2.3.1. Slump Test. It was conducted on fresh concrete by measuring the workability of concrete in terms of slump reduction in accordance with BS EN 12350-2 [34].

2.3.2. Hardened Concrete. The compressive, splitting tensile, flexural strength and the density of the hardened concrete were evaluated in this study. The cube samples $(100 \times 100 \times 100 \mathrm{~mm})$ were cast to investigate the compressive strength of concrete under BS EN 12390-3 [35], and the cylindrical specimens $(200 \times 100 \mathrm{~mm})$ were made for examining the indirect tensile test by following BS EN 12390-6 [36]. Similarly, the concrete prisms $(500 \times 100 \times 100 \mathrm{~mm})$ were cast for the flexural strength of concrete using BS EN 12390-5 [37]. All the concrete specimens were cured after 7, 28 , and 56 days. The density of concrete was calculated by using BS 12390-7 [38] at 28 days. Also, the water penetration test of concrete was conducted as per BS EN 12390-8:2009 [39] after 28 days, and the carbonation depth of concrete test was conducted by using phenolphthalein method after 28 , 90 , and 180 days. Besides, the drying shrinkage of concrete was evaluated following the BS ISO 1920-8, 2009 [40], at 40 days.

\section{Results and Discussion}

3.1. Workability of Concrete. Figure 1 illustrates the workability of fresh concrete mixes with the inclusion of $0 \%-20 \%$ of BCM. The result showed that the workability reduces with an increasing percentage of BCM in concrete. This decrement in the slump value is due to some amount of water absorbed by metakaolin and GGBFS. The trend of the result is similar to that observed in the work of Bheel et al. [41, 42] where a reducing slump value is obtained with an increasing percentage of limestone and sugarcane bagasse ash [41], and corn cob ash and glass powder [42] as a binary cementitious material in concrete. However, a water-reducing admixture can be introduced to improve the workability of the concrete.

3.2. Density of Concrete. Figure 2 presents the density of concrete with the addition of metakaolin and GGBFS after 28 days. The experimental outcomes indicated that the density of the concrete with the introduction of $5 \%, 10 \%$, $15 \%$, and $20 \%$ BCM achieved $1.88 \%, 3.56 \%, 5.03 \%$, and $6.92 \%$, respectively, lower density than concrete with the inclusion of $0 \%$ of BCM after 28 days. It was detected that the density is reduced as the quantity of BCM increases in concrete. This decrement in the density of concrete with the addition of $\mathrm{BCM}$ is due to the specific gravity of cement being higher than that of metakaolin and GGBFS. This observation is similar to that of [5], where the density of concrete decreases with increasing marble and tile powder content in concrete after 28 days. Also, Raza et al. [43] reported that the concrete density decreases as the amount of wood waste ash increases in concrete after 28 days.

3.3. Compressive Strength. The compressive strength test was conducted on hardened concrete with inclusion $0 \%-20 \%$ of $\mathrm{BCM}$ for 7,28 , and 56 days, and the results presented in Figure 3. The outcome indicates that the compressive strength was enhanced while using BCM up to $10 \%$ for 7,28 , and 56 days. The optimum compressive strength was achieved by $8.45 \%, 12.28 \%$, and $13 \%$ at $10 \%$ of BCM and the minimum values were calculated by $17.27 \%, 9.23 \%$, and $8.69 \%$ while using $20 \%$ of BCM after 7,28 , and 56 days, respectively. This experimental study clarifies that the compressive strength is decreased by using $10 \%$ of BCM in the concrete mix. This decrement in strength is because concrete becomes more porous which results in lesser strength. On the other hand, this is due to the existence of metakaolin and GGBFS materials; concrete reduces its water content. Subsequently, MK and GGBFS absorbed more amount of water. Resultantly, this reduction in water content might slow the hydration process of concrete, which causes a decrease in strength after ever curing periods. This shows that the incorporation of $10 \% \mathrm{MK}$ was optimum in terms of compressive strength, which is better than the $15 \%$ replacement described in an earlier study with a water/binder ratio of 0.30 [19]. Bheel et al. [42] indicated that the compressive strength was improved while using $10 \%$ of BCM in concrete after 28 days. Similarly, Bheel et al. [5] described that the use of marble and tile powder up to $10 \%$ as cementitious material caused an increase in strength after 28 days.

3.4. Splitting Tensile Strength. Figure 4 presents the split tensile strength of concrete by incorporating $0 \%-20 \%$ of $\mathrm{BCM}$ in concrete after 7,28 , and 56 days. The indirect tensile strength was estimated by $5.65 \%, 9.33 \%$, and $9.67 \%$ at $10 \%$ of 
TABLE 3: Mixtures composition.

\begin{tabular}{|c|c|c|c|c|c|c|}
\hline Mixture ID & PC (\%) & MK (\%) & GGBFS (\%) & Water/cement ratio (\%) & Fine aggregate (\%) & Coarse aggregate (\%) \\
\hline 0BCM & 100 & 0 & 0 & 0.54 & 100 & 100 \\
\hline 5BCM & 95 & 2.50 & 2.50 & 0.54 & 100 & 100 \\
\hline 10BCM & 90 & 5 & 5 & 0.54 & 100 & 100 \\
\hline 15BCM & 85 & 7.50 & 7.50 & 0.54 & 100 & 100 \\
\hline 20BCM & 80 & 10 & 10 & 0.54 & 100 & 100 \\
\hline
\end{tabular}

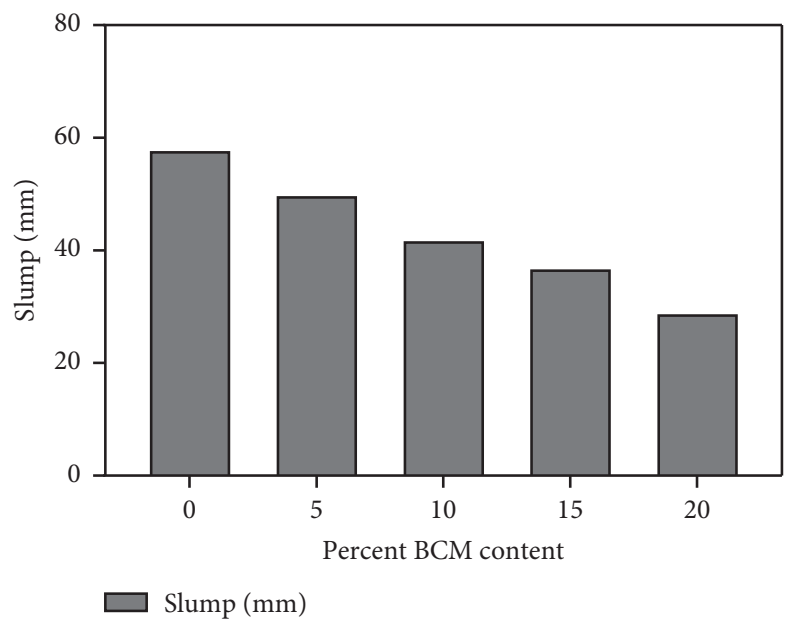

FIGURE 1: Workability of concrete.

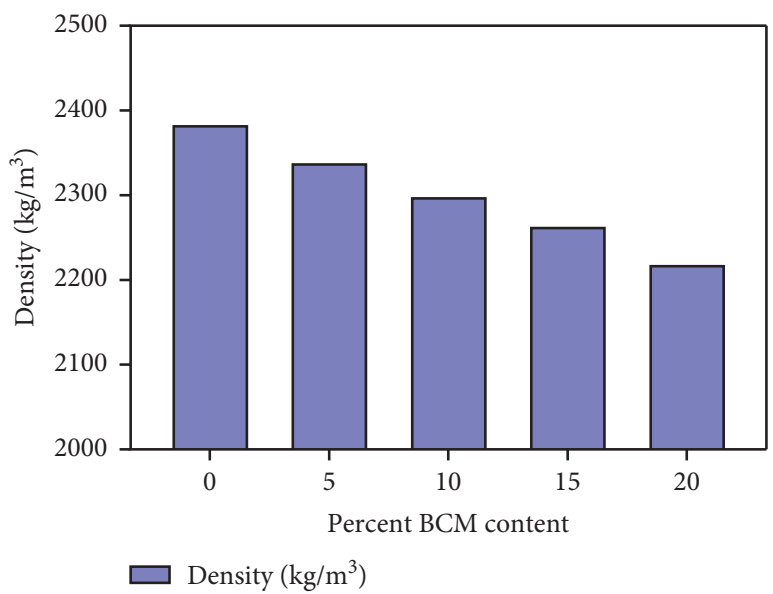

FIgURE 2: Density of concrete after 28 days.

$\mathrm{BCM}$ is higher than concrete with inclusion $0 \%$ of BCM in concrete after 7,28 , and 56 days, respectively. Similarly, lower split tensile strength was measured by $14.78 \%, 11.67 \%$, and $9.70 \%$ while using $20 \%$ of BCM in concrete after 7, 28, and 56 days, respectively. The reduction in split tensile strength is due to the increase in the surface area of $\mathrm{MK}$ and GGBFS in concrete. This observation correlated with that of Bheel et al. [42] where they presented that the split tensile strength of concrete was inclined as the content of BCM increases up to $10 \%$ after 28 days. Similarly, Raza et al. [43] stated that the tensile strength was improved at $10 \%$ of wood waste ash in concrete after 7, 28, 56, and 90 days, respectively. This same trend is observed by Bheel et al. [41] as they

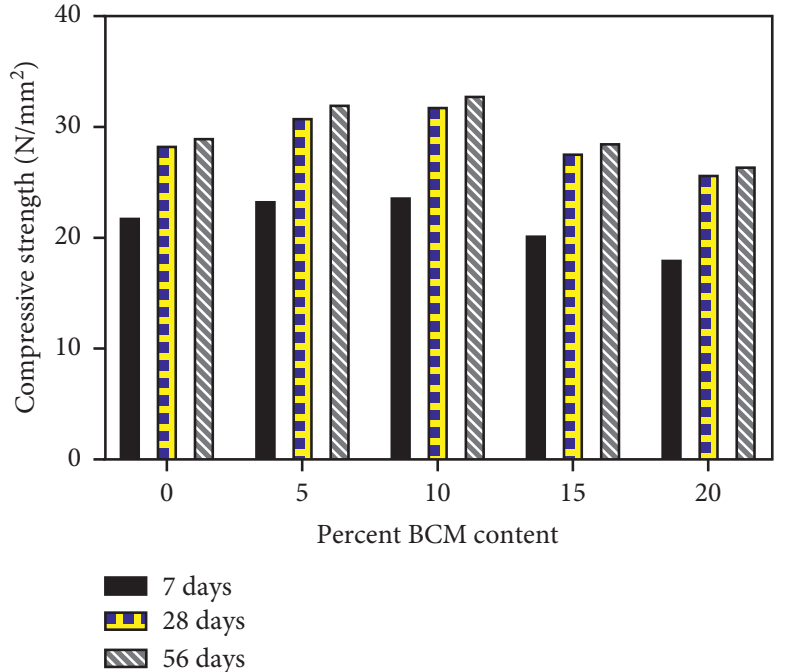

FIgURE 3: Compressive strength of concrete.

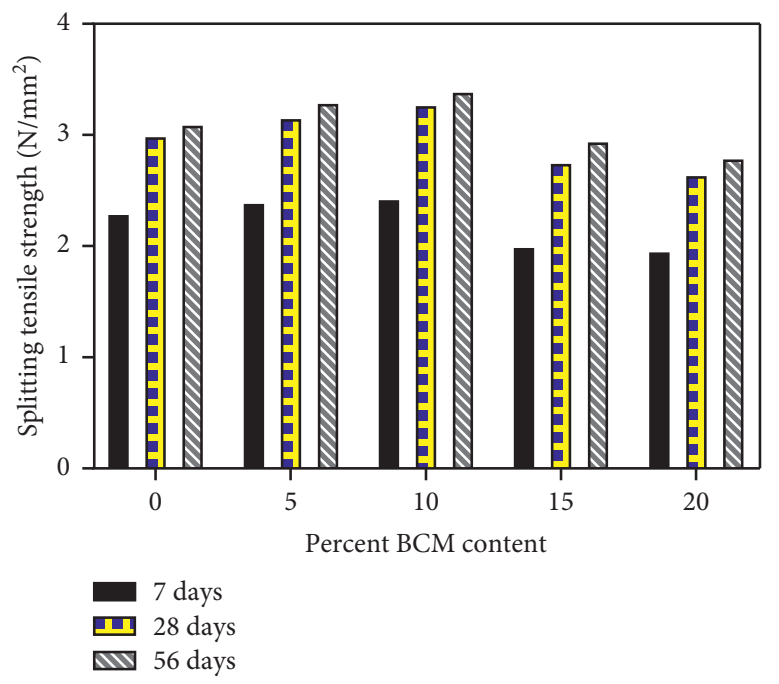

FIGURE 4: Splitting tensile strength.

informed that the indirect tensile strength was inclined while using up to $10 \%$ of limestone and sugar cane bagasse ash in concrete after 28 days.

3.5. Flexural Strength. Figure 5 shows the flexural strength of concrete with inclusion $0 \%-20 \%$ of BCM in concrete after 7 , 28 , and 56 days. It was noticed that flexural strength was improved by $5.15 \%, 9.93 \%$, and $10.20 \%$ at $10 \%$ of BCM after 7,28 , and 56 days, respectively. This increment in flexural 


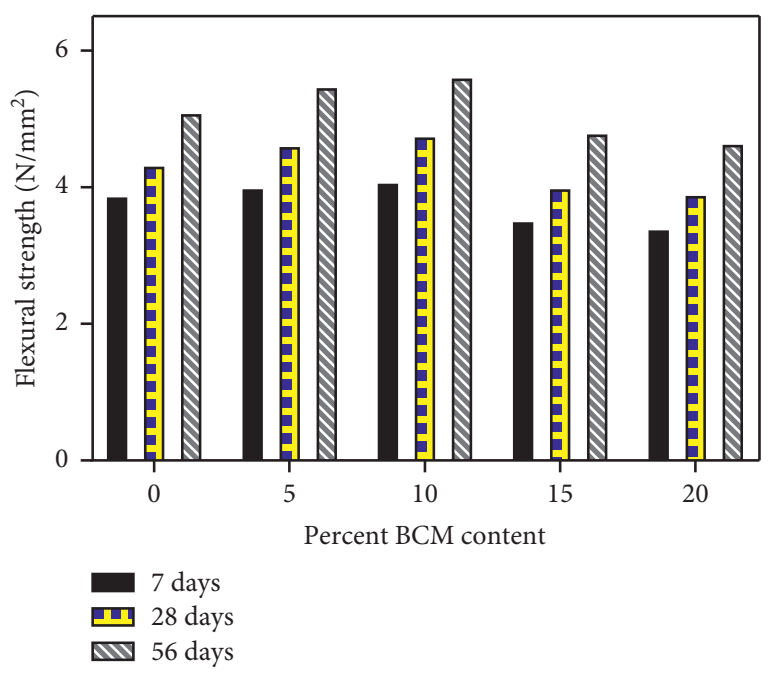

FIgURE 5: Flexural strength of concrete.

strength is due to the presence of a high amount of silica, $\mathrm{Al}_{2} \mathrm{O}_{3}$, and $\mathrm{Fe}_{2} \mathrm{O}_{3}$ and producing cement clinker. Similarly, the minimum strength was achieved by $12.37 \%, 10 \%$, and $8.82 \%$ at $20 \%$ of BCM in concrete after 7,28 , and 56 days, respectively. The decline in strength caused by an additional amount of BCM is due to its slow pozzolanic activity at every time period. Similarly, Dinakar et al. [19] reported an improved flexural strength at $10 \%$ of metakaolin after 28 days.

3.6. Permeability of Concrete. Figure 6 presents the plot of the permeability of concrete with the addition of several proportions of BCM after 28 days. The maximum permeability is estimated as $19.5 \mathrm{~mm}$ at $0 \%$ of BCM, and the minimum was calculated as $9 \mathrm{~mm}$ while using $20 \%$ of BCM in concrete after 28 days. It was revealed that the water penetration depth reduced as the content of BCM improves in concrete every day. This observation is correlated with that of Guneyisi et al. [44] as they reported that the permeability of concrete declined as the content of MK increases (up to 15\%) after every curing period. Moreover, the permeability of concrete is an essential feature of the durability of concrete, and lower water penetration depth of concrete showed high resistance against chemical attacks [45].

3.7. Chloride Attack Test. As shown in Figure 7, the effect of chloride on the concrete without BCM is more than that of concrete with BCM. An increase in the amount of BCM in concrete that results in reducing the chloride attack effect in concrete was noted. It can be concluded that mineral additives can better fill the concrete cavity due to fine particles. They can also increase the resistance of concrete against harmful impacts caused by chloride. Replacing cement with BCM in concrete mix design can also be profitable economically. However, BCM is also used instead of cement in concrete mixes to provide significant economic benefits. This observation is agreed on by Dharani et al., [46] that the concrete blended with GSA has better resistance to the chloride attack as compared to control mix concrete.

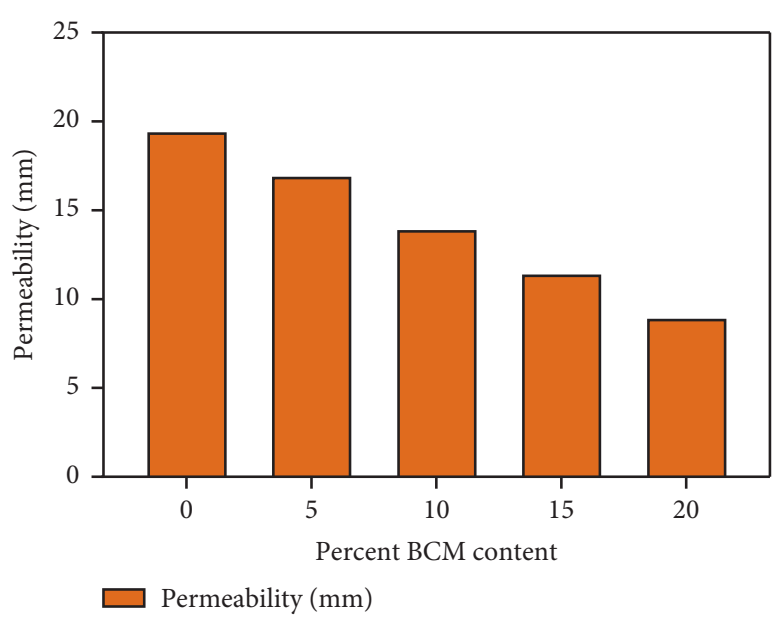

Figure 6: Permeability of concrete containing BCM after 28 days.

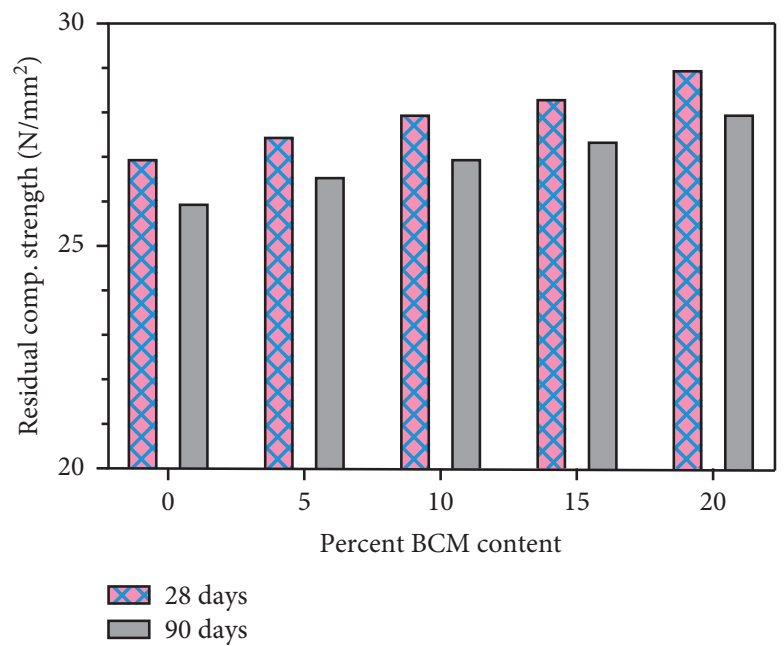

FIGURE 7: Residual compressive strength of samples exposed to chloride attacks.

3.8. Carbonation Depth Test. Figure 8 presents the carbonation depth of the mixture with the inclusion of various proportions of MK and GGBFS as binary cementitious material after 28,90 , and 180 days. The maximum outcomes of carbonation depth were recorded as $11 \mathrm{~mm}, 14 \mathrm{~mm}$, and $19 \mathrm{~mm}$ at $20 \%$ of $\mathrm{BCM}$, and minimum findings were estimated as $7 \mathrm{~mm}, 9 \mathrm{~mm}$, and $12 \mathrm{~mm}$ at $10 \%$ of BCM after 28 , 90 , and 180 days, respectively. It was revealed that the carbonation depth was reduced as the content of $\mathrm{BCM}$ increased up to $10 \%$. After $10 \%$ of $\mathrm{BCM}$, it starts improving. This decrement in the carbonation depth of concrete is due to the pozzolanic activity of minerals admixtures [47].

3.9. Drying Shrinkage of Concrete. Figure 9 presents the effect of BCM on the drying shrinkage of the concrete. It can be seen that the drying shrinkage of concrete reduced with the increase in BCM content. This reduction in drying shrinkage of cement pastes is due to the following reasons: (i) cement dilution by BCM, a smaller amount of cement producing less shrinkage, 


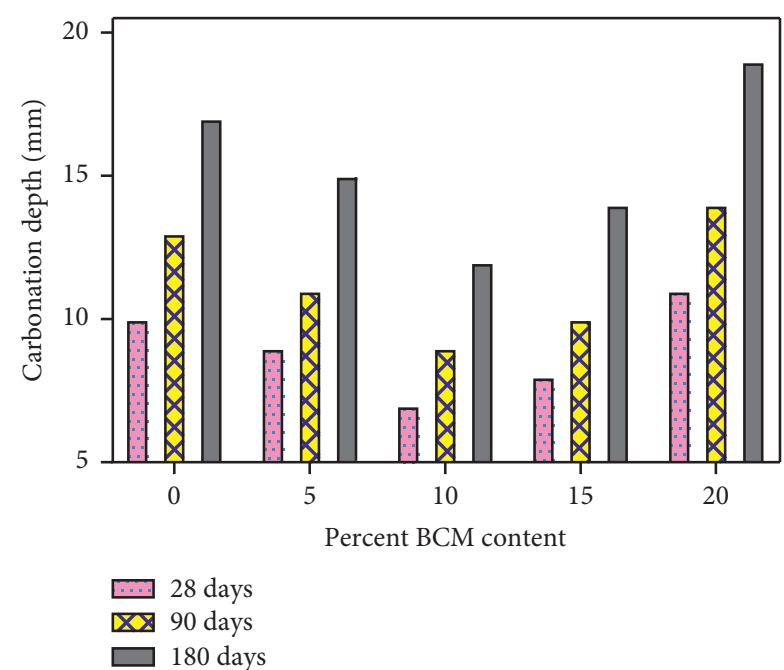

Figure 8: Carbonation depth of concrete containing BCM.

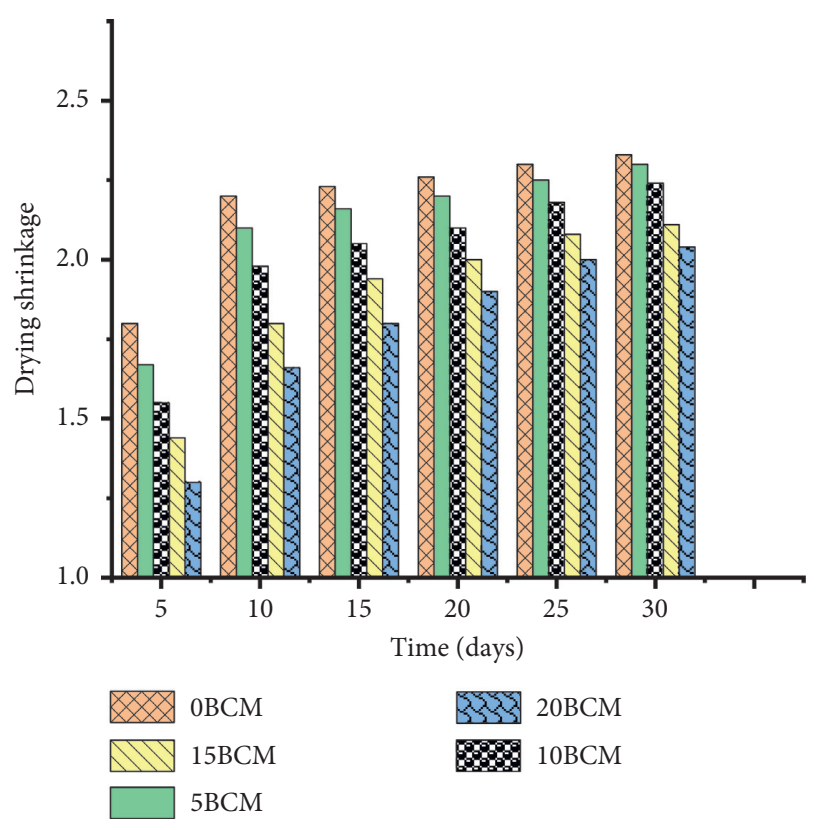

Figure 9: Drying shrinkage of concrete containing BCM.

(ii) pozzolanic reaction of $\mathrm{BCM}$ with $\mathrm{CH}$ formed by cement, and (iii) increase in capillary tension [48-50]. This observation is similar to that of [51-54] where rice husk ash (RHA) is used as a partial replacement for cement in concrete. The drying shrinkage is significantly reduced compared to samples without RHA. This may be due to a lower cement content compared to the control mixture, as well as the pore size and grain size refinement process which improves the mechanical interlocking in the transition zone. Therefore, when shrinkage is a problem, the use of RHA can be part of a mitigation strategy.

\section{Conclusion}

In this investigation, metakaolin and GGBFS were utilized as a binary cementitious material up to $20 \%$ for determining the mechanical properties of fresh and hardened concrete. On the basis of the test results, the following is concluded: (i) The workability of fresh concrete was measured by $16 \%, 27.58 \%, 36.20 \%$, and $50 \%$ while using $5 \%$, $10 \%, 15 \%$, and $20 \%$ of BCM, which is smaller than concrete with the introduction of $0 \% \mathrm{BCM}$ in concrete. The result showed that the workability is increased with increase in the content of BCM in concrete.

(ii) The density was achieved by $1.88 \%, 3.56 \%, 5.03 \%$, and $6.92 \%$ with the introduction of $5 \%, 10 \%, 15 \%$, and $20 \%$ metakaolin and GGBFS as BCM are lower than that of concrete with the addition of $0 \%$ of BCM after 28 days, respectively.

(iii) The compressive strength, split tensile strength, and flexural strength of the concrete were enhanced by $12.28 \%, 9.33 \%$, and $9.93 \%$ at $10 \%$ of BCM after 28 days, respectively. The increment in strength may be attributed to the effect of pore filling and the pozzolanic reaction of the BCM. But after $10 \%$ of $\mathrm{BCM}$, it starts reducing in mechanical properties due to the dilution effect of the BCM on the PC.

(iv) The water penetration depth of concrete reduced as the amount of BCM increases in concrete at 28 days.

(v) The effect of chloride on the concrete without BCM is more than that of concrete with BCM.

(vi) The carbonation depth decreased with increases in the content up to $10 \%$ of BCM and later increases.

(vii) The drying shrinkage of concrete reduced with increases in the content of BCM.

\section{Data Availability}

The datasets generated during the current study are available from the corresponding author on request.

\section{Conflicts of Interest}

The authors declare that they have no conflicts of interest.

\section{References}

[1] S. Ghosal and S. Moulik, "Use of rice husk ash as partial replacement with cement in concrete- A review," International Journal of Engineering Research, vol. 4, no. 9, pp. 506-509, 2015.

[2] A. M. Neville and J. J. Brooks, Concrete Technology, Pearson Education Asia, Pte Ltd, Singapore, 2008.

[3] M. Alexander and S. Mindness, Aggregates in Concrete, Taylor and Francis Group, London, UK, 2005.

[4] P. V. Naidu and P. K. Pandey, "Replacement of cement in concrete," International Journal of Environmental Research and Public Health, vol. 4, pp. 91-98, 2014.

[5] N. Bheel, K. A. Kalhoro, T. A. Memon, Z. U. Z. Lashari, M. A. Soomro, and U. A. Memon, "Use of marble powder and tile powder as cementitious materials in concrete," Engineering, Technology \& Applied Science Research, vol. 10, no. 2, pp. 5448-5451, 2020.

[6] A. M. Neville, Properties of Concrete, Pearson Education Asia Pte. Ltd., London, UK, 2000. 
[7] V. Ramasamy, "Compressive strength and durability properties of rice husk ash concrete," KSCE Journal of Civil Engineering, vol. 16, no. 1, pp. 93-102, 2012.

[8] N. Bheel, M. A. Jokhio, J. A. Abbasi, H. B. Lashari, M. I. Qureshi, and A. S. Qureshi, "Rice husk ash and fly ash effects on the mechanical properties of concrete," Engineering, Technology \& Applied Science Research, vol. 10, no. 2, pp. 5402-5405, 2020.

[9] J. P. Broomfield, "Corrosion of Steel in Concrete:" Understanding, Investigation and Repair, CRC Press, Boca Raton, FL, USA, 2nd edition, 2006.

[10] N. D. Bheela, F. A. Memonb, S. L. M. A. W. Abroa, and I. A. Shara, "Millet husk ash as environmental friendly material in cement concrete," in Proceedings of the 5th International Conference on Energy, Environment and Sustainable Development, Mehran UET Jamshoro, vol. 1, Energy and Environment Engineering Research Group, Sindh, Pakistan, vol, 1, pp. 153-158, 2018.

[11] R. R. Hussain and T. Ishida, "Critical carbonation depth for initiation of steel corrosion in fully carbonated concrete and development of electrochemical carbonation induced corrosion model," International Journal of Electrochemical Science, vol. 4, no. 8, pp. 1178-1195, 2009.

[12] N. Kad and M. Vinod, "Review research paper on influence of rice husk ash on the properties of concrete," International Journal of Research, vol. 2, no. 5, pp. 873-877, 2015.

[13] M. Valipour, F. Pargar, M. Shekarchi, and S. Khani, "Comparing a natural pozzolan, zeolite, to metakaolin and silica fume in terms of their effect on the durability characteristics of concrete: a laboratory study," Construction and Building Materials, vol. 41, pp. 879-888, 2013.

[14] P. Duan, Z. Shui, W. Chen, and C. Shen, "Effects of metakaolin, silica fume and slag on pore structure, interfacial transition zone and compressive strength of concrete," Construction and Building Materials, vol. 44, pp. 1-6, 2013.

[15] J. J. Brooks, M. A. Megat Johari, and M. Mazloom, "Effect of admixtures on the setting times of high-strength concrete," Cement and Concrete Composites, vol. 22, no. 4, pp. 293-301, 2000.

[16] C. S. Poon, S. C. Kou, and L. Lam, "Compressive strength, chloride diffusivity and pore structure of high performance metakaolin and silica fume concrete," Construction and Building Materials, vol. 20, no. 10, pp. 858-865, 2006.

[17] X. Jin and Z. Li, "Effects of mineral admixture on properties of young concrete," Journal of Materials in Civil Engineering, vol. 15 , no. 5, pp. 435-442, 2003.

[18] M. Si-Ahmed, A. Belakrouf, and S. Kenai, "Influence of metakaolin on the performance of mortars and concretes," in Proceedings of the World Academy of Science, Engineering and Technology, p. 1354, Amsterdam, The Netherlands, 2012.

[19] P. Dinakar, P. K. Sahoo, and G. Sriram, "Effect of metakaolin content on the properties of high strength concrete," International Journal of Concrete Structures and Materials, vol. 7, no. 3, pp. 215-223, 2013.

[20] J. Ambroise, S. Maximilien, and J. Pera, "Properties of metakaolin blended cements," Advanced Cement Based Materials, vol. 1, no. 4, pp. 161-168, 1994.

[21] A. K. Parande, B. Ramesh Babu, M. Aswin Karthik, K. K. Deepak Kumaar, and N. Palaniswamy, "Study on strength and corrosion performance for steel embedded in metakaolin blended concrete/ mortar," Construction and Building Materials, vol. 22, no. 3, pp. 127-134, 2008.
[22] S. Arivalagan, "Sustainable studies on concrete with GGBS as a replacement material in cement," Jordan Journal of Civil Engineering, vol. 159, no. 3147, pp. 1-8, 2014.

[23] M. Elchalakani, T. Aly, and E. Abu-Aisheh, "Sustainable concrete with high volume GGBFS to build Masdar city in the UAE," Case Studies in Construction Materials, vol. 1, pp. 10-24, 2014.

[24] S. K. Karri, G. R. Rao, and P. M. Raju, "Strength and durability studies on GGBS concrete," SSRG International Journal of Civil Engineering (SSRG-IJCE), vol. 2, no. 10, pp. 34-41, 2015.

[25] H. Y. Wang, "The effects of elevated temperature on cement paste containing GGBFS," Cement and Concrete Composites, vol. 30, no. 10, pp. 992-999, 2008.

[26] W.-T. Kuo, H.-Y. Wang, and C.-Y. Shu, "Engineering properties of cementless concrete produced from GGBFS and recycled desulfurization slag," Construction and Building Materials, vol. 63, pp. 189-196, 2014.

[27] M. Shariq, J. Prasad, and A. Masood, "Effect of GGBFS on time dependent compressive strength of concrete," Construction and Building Materials, vol. 24, no. 8, pp. 1469-1478, 2010.

[28] M. V. Shoubi, A. S. Barough, and O. Amirsoleimani, "Assessment of the roles of various cement replacements in achieving the sustainable and high performance concrete," International Journal of Advances in Engineering \& Technology, vol. 6, no. 1, p. 68, 2013.

[29] D. Suresh and K. Nagaraju, "Ground granulated blast slag (GGBS) in concrete-a review," IOSR Journal of Mechanical and Civil Engineering, vol. 12, no. 4, pp. 76-82, 2015.

[30] R. Siddique and D. Kaur, "Properties of concrete containing ground granulated blast furnace slag (GGBFS) at elevated temperatures," Journal of Advanced Research, vol. 3, no. 1, pp. 45-51, 2012.

[31] P. W. Leung and H. D. Wong, Final Report on Durability and Strength Development of Ground Granulated Blast Furnace Slag Concrete, Geotechnical Engineering Office, Civil Engineering and Development Department, the Government of Hong Kong, Hong Kong, China, 2010.

[32] W. Ling, T. Pei, and Y. Yan, "Application of ground granulated blast furnace slag in high-performance concrete in China," in Proceedings of the International Workshop on Sustainable Development and Concrete Technology, Organized by China Building Materials Academy, PRC, Beijing, China, pp. 309-317, 2004.

[33] V. Cervantes and J. Roesler, "Ground granulated blast furnace slag," pp. 1-4, Center of Excellence for Airport Technology, Champaign, IL, USA, 2007, Technical Note.

[34] BS EN 12350-2, Testing Fresh Concrete, Part 2: Slump-Test, BSI, London, UK, 2009.

[35] BS EN 12390-3, Testing Harden Concrete. Compressive Strength of Test Specimens, BSI, London, UK, 2009.

[36] BS EN 12390-6, Testing Hardened Concrete. Tensile Splitting Strength of Test Specimens, BSI, London, UK, 2009.

[37] BS EN 12390-5, Testing Hardened concrete. Flexural Strength of Test Specimens, BSI, London, UK, 2009.

[38] British Standards Institution, BS EN 12390-7:2000 Part 7: Density of Hardened Concrete, BSI, London, UK, 2000.

[39] British Standard Institution, BS EN 12390-8: Testing Hardened Concrete: Part 8: Depth of Penetration of Water under Pressure, BSI, London, UK, 2009.

[40] BS ISO 1920-8, Determination of Drying Shrinkage of Concrete for Samples Prepared in the Field or in the Laboratory, BSI, London, UK, 2009. 
[41] N. Bheel, A. S. Memon, I. A. Khaskheli, N. M. Talpur, S. M. Talpur, and M. A. Khanzada, "Effect of sugarcane bagasse ash and lime stone fines on the mechanical properties of concrete," Engineering, Technology \& Applied Science Research, vol. 10 , no. 2, pp. 5534-5537, 2020.

[42] N. Bheel and A. Adesina, "Influence of Binary Blend of Corn Cob Ash and Glass Powder as Partial Replacement of Cement in Concrete," Silicon, pp. 1-8, 2020.

[43] M. S. Raza, R. A. I. Kunal, D. Kumar, and A. L. I. Mutahar, "Experimental study of physical, fresh-state and strength parameters of concrete incorporating wood waste ash as a cementitious material," Journal of Materials and Engineering Structures (JMES), vol. 7, no. 2, pp. 267-276, 2020.

[44] G. J. Z. Xu, D. F. Watt, and P. P. Hudec, "Effectiveness of mineral admixtures in reducing ASR expansion," Cement and Concrete Research, vol. 25, no. 6, pp. 1225-1236, 1995.

[45] A. A. Ramezanianpour, A. Pilvar, M. Mahdikhani, and F. Moodi, "Practical evaluation of relationship between concrete resistivity, water penetration, rapid chloride penetration and compressive strength," Construction and Building Materials, vol. 25, no. 5, pp. 2472-2479, 2011.

[46] D. Dharani and V. Arivu Thiravida Selvan, "Durability studies on concrete by using groundnut shell ash as mineral admixture," International Journal for Innovative Research in Science \& Technology, vol. 3, no. 10, pp. 168-172, 2017.

[47] P. Duan, Z. Shui, W. Chen, and C. Shen, "Influence of metakaolin on pore structure-related properties and thermodynamic stability of hydrate phases of concrete in seawater environment," Construction and Building Materials, vol. 36, pp. 947-953, 2012.

[48] J. J. Brooks and M. A. Megat Johari, "Effect of metakaolin on creep and shrinkage of concrete," Cement and Concrete Composites, vol. 23, no. 6, pp. 495-502, 2001.

[49] S. Wild, J. M. Khatib, and L. J. Roose, "Chemical shrinkage and autogenous shrinkage of Portland cement-metakaolin pastes," Advances in Cement Research, vol. 10, no. 3, pp. 109-119, 1998.

[50] J. M. Kinuthia, S. Wild, B. B. Sabir, and J. Bai, "Self-compensating autogenous shrinkage in Portland cement-metakaolin-fly ash pastes," Advances in Cement Research, vol. 12, no. 1 , pp. $35-43,2000$.

[51] B. Chatveera and P. Lertwattanaruk, "Durability of conventional concretes containing black rice husk ash," Journal of Environmental Management, vol. 92, no. 1, pp. 59-66, 2011.

[52] G. A. Habeeb and M. M. Fayyadh, "Rice husk ash concrete: the effect of RHA average particle size on mechanical properties and drying shrinkage," Australian Journal of Basic and Applied Sciences, vol. 3, no. 3, pp. 1616-1622, 2009.

[53] S. I. Khassaf, A. T. Jasim, and F. K. Mahdi, "Investigation the properties of concrete containing rice husk ash to reduction the seepage in canals," International Journal of Scientific Technology Research, vol. 3, no. 4, pp. 348-354, 2014.

[54] H. B. Mahmud, M. F. A. Malik, R. A. Kahar, M. F. M. Zain, and S. N. Raman, "Mechanical properties and durability of normal and water reduced high strength grade 60 concrete containing rice husk ash," Journal of Advanced Concrete Technology, vol. 7, no. 1, pp. 21-30, 2009. 